\title{
PENGOLAHAN CENGPO 'KEMOCENG KELOPO’ UNTUK MENUNJANG PEREKONOMIAN MASYARAKAT DESA PLOSO KECAMATAN TEGALOMBO KABUPATEN PACITAN
}

\author{
Winarsih, Sulis Setiani, Mufida Windy Istiani \\ Pendidikan Ekonomi FKIP UNIVERSITAS PGRI MADIUN \\ winarsih_aje@gmail.com \\ Pendidikan Guru Sekolah Dasar FKIP UNIVERSITAS PGRI MADIUN \\ culiscetiani@gmail.com \\ Pendidikan Guru Sekolah Dasar FKIP UNIVERSITAS PGRI MADIUN \\ mufidawindy261@gmail.com
}

\begin{abstract}
Ploso Village is one of 11 villages in Tegalombo sub-district, Pacitan regency, which is $23 \mathrm{~km}$ to the north from the district center and has an area of 701.49 hectares. The majority of the villagers work as farmers with coconut as the main commodity. The author took the initiative to introduce a product derived from the waste of coconut fibers considering the use of coconut trees only on the fruit, shell and tree alone. This product is named "CENGPO" Kemoceng kelopo (Java language), which is the duster derived from fibers (coconut). The function of the duster is the same as the duster in general, it's just made of coconut fiber material. Usefulness of the Student Creativity Program (PKM) in the field of Society is to provide training to the community of Ploso Village, especially the mothers of PKK in order to develop their creativity in the home industry.
\end{abstract}

Keywords : Processing Kemoceng Kelopo, Community Economy.

\begin{abstract}
Abstrak
Desa Ploso merupakan salah satu dari 11 desa di wilayah Kecamatan Tegalombo, Kabupaten Pacitan, yang terletak $23 \mathrm{~km}$ ke arah utara dari pusat kecamatan dan memiliki luas wilayah 701,49 hektar. Mayoritas penduduk di desa tersebut bekerja sebagai petani dengan kelapa sebagai komoditas utama. penulis berinisiatif memperkenalkan suatu produk yang berasal dari limbah serabut kelapa mengingat pemanfaat dari pohon kelapa hanya pada buah, tempurung dan pohonnya saja. Produk ini bernama "CENGPO" Kemoceng Kelopo (bahasa jawa), yaitu kemoceng yang berasal dari serabut kelopo (kelapa). Fungsi dari kemoceng ini sama halnya dengan kemoceng pada umumnya, hanya saja terbuat dari bahan serabut kelapa. Kegunaan dari Program Kreativitas Mahasiswa (PKM) di bidang Kemasyarakatan ini yaitu untuk memberikan pelatiha2n kepada masyarakat Desa Ploso terutama ibu-ibu PKK agar mampu mengembangkan kreatifitasnya dalam industri rumahan (home industry).
\end{abstract}

Kata Kunci : Pengolahan Kemoceng Kelopo, Perekonomian Masyarakat. 


\section{PENDAHULUAN}

Pacitan merupakan salah satu kabupaten di Jawa Timur yang terkenal dengan destinasti pariwisata alam dan hasil bumi. Salah satunya Desa Ploso, Kecamatan Tegalombo. Desa Ploso merupakan salah satu dari 11 desa di wilayah Kecamatan Tegalombo, Kabupaten Pacitan, yang terletak $23 \mathrm{~km}$ ke arah utara dari pusat kecamatan. Desa Ploso mempunyai luas wilayah seluas 701,49 hektar. Iklim Desa Ploso sebagaimana desa-desa lain di wilayah Indonesia mempunyai iklim kemarau dan penghujan, hal tersebut mempunyai pengaruh langsung terhadap pola tanam yang ada di Desa Ploso.

Desa Ploso terdiri dari 5 dusun dengan jumlah penduduk 3.996 jiwa atau $910 \mathrm{KK}$. Dengan penduduk usia produktif \pm 914 jiwa. Karena Desa Ploso merupakan desa pertanian, maka sebagian besar penduduknya bermata pencaharian sebagai petani. $65 \%$ penduduk di Desa Ploso bermata pencaharian sebagai petani.

Adapun hasil pertanian yang dihasilkan dari Desa Ploso, antara lain kelapa, kopi, kedelai, cengkeh, jagung, dan padi. Komoditas utama dari daerah ini adalah Kelapa, jagung, dan padi. Hasil panen tersebut biasanya dijual ke pasar atau kepada pedagang bahan makanan, dalam keadaan mentah atau belum diolah. Belum ada penghasilan tambahan bagi para petani di daerah tersebut. Belum ada pengolahan hasil panen, terutama kelapa yang merupakan komoditas utama di Desa Ploso.

Mengingat bahwa pohon kelapa bisa dimanfaatkan mulai dari daging sampai akarnya. Maka, penulis berinisiatif memberikan solusi berupa pelatihan kepada
Terutama untuk memperkenalkan kembali produk-produk dalam negeri yang unik dan terjangkau. Melalui pemanfaatan salah satu komponen buah kelapa berupa serabut untuk membuat suatu produk yang mampu menunjang perekonomian masyarakat Desa Ploso. Apalagi mayoritas penduduk memang menggunakan daging buah kelapa sebagai bahan masakan dan sebagian dijual ke pedagang di pasar-pasar tradisional, tempurungnya digunakan untuk membuat arang, akan tetapi mereka belum mampu mengoptimalkan pemanfaatkan limbah dari kelapa yang berupa serabut. Biasanya serabut tersebut hanya dibiarkan berserakan atau ada juga yang menjualnya dalam bentuk bahan mentah ke pabrik-pabrik untuk dijadikan kerajianan. Padahal jika serabut kelapa tersebut diolah secara mandiri oleh masyarakat desa Ploso, tentunya dapat menambah penghasilan masyarakat serta menciptakan lapangan pekerjaan.

Produk ini bernama "CENGPO" Kemoceng Kelopo (bahasa jawa), yaitu kemoceng yang berasal dari serabut kelopo (kelapa). Fungsi dari kemoceng ini sama halnya dengan kemoceng pada umumnya, hanya saja terbuat dari bahan serabut kelapa. Harga dari kemoceng tersebut juga cukup terjangkau. Meskipun keberadaan kemoceng ini sering terabaikan, tetapi barang ini sangat praktis jika digunakan untuk membersihkan benda dari kotoran/debu.

Saat ini kemoceng yang beredar di pasaran dijual harga beli yang cukup tinggi, dan banyaknya limbah serabut kelapa di Desa Ploso tetapi masyarakat kurang mampu untuk memanfaatkannya, maka penulis ingin memperkenalkan suatu produk 
Winarsih, Sulis, dan Mufida, Pengolahan Cengpo 'Kemoceng K elopo' | 191

kualitas dan bahan-bahannya yang sangat mudah didapat. Selain itu harga produk ini sangat terjangkau bagi masyarakat.

\section{METODE PENELITIAN}

Dalam pelakasanaan program kreatifitas mahasiswa kami menggunakan metode pelatihan Cengpo dibagi menjadi tiga waktu :

\section{Teknik Penyuluhan}

Dalam kegiatan ini yang pertama kali di lakukan adalah Observasi (pengumpulan data mengenai kondisi masyarakat di Desa Ploso). Kemudian mengajukan Surat Ijin Permohonan kerjasama kepada Kepala Desa Ploso untuk melaksanakan program tersebut. Setelah program disetujui, langkah selanjutnya yaitu melakukan Perencanaan Anggaran guna mempersiapkan bahan yang akan dibeli untuk keperluan produksi.

\section{Pelatihan (pelaksanaan program)}

Sebelum melakukan kegiatan pelatihan, yang kami lakukan adalah mengadakan sosialisasi dilakukan di Desa Ploso kepada ibu-ibu PKK untuk memberikan penjelasan mengenai program tersebut, serta mendemonstrasikan cara pembuatan Cengpo dan menunjukkan kepada masyarakat bagaimana bentuk serta kualitasnya. Tujuannya untuk membekali ketrampilan dalam pengolahan hasil panen mereka guna menambah pendapatan masyarakat di Desa Ploso tersebut. Sosialisasi dilaksanakan pada saat acara arisan ibu-ibu PKK. adalah pembelian alat dan bahan pembuatan "Cengpo" dalam skala yang lebih besar.

Berikut adalah Alat dan Bahan serta Cara pembuatan untuk 1 produk Cengpo;

a. Alat dan bahan yang diperlukan pada pengolahan "CENGPO" Kemoceng Kelopo

Tabel 3.1 Alat Pembuatan Cengpo

\begin{tabular}{|l|l|c|}
\hline No. & Alat & Jumlah \\
\hline 1. & Parang & 2 \\
\hline 2. & Pisau & 2 \\
\hline 3. & Gunting & 2 \\
\hline 4. & Palu & 2 \\
\hline 5. & Kayu & 2 \\
\hline 6. & Keranjang & 1 \\
\hline 7. & Sisir & 2 \\
\hline
\end{tabular}

Tabel 3.2 Bahan Pembuatan Cengpo, untuk 1 buah

\begin{tabular}{|l|l|l|}
\hline No. & Alat & Jumlah \\
\hline 1. & $\begin{array}{l}\text { Serabut } \\
\text { kelapa }\end{array}$ & 5 buah \\
\hline 2. & Lem & 1 kaleng \\
\hline 3. & $\begin{array}{l}\text { Bambu } \\
\text { kecil }\end{array}$ & 1 buah \\
\hline 4. & $\begin{array}{l}\text { Benang } \\
\text { sol }\end{array}$ & 1 meter \\
\hline 5. & Pilok & $\begin{array}{l}1 \text { warna atau } \\
\text { sesuai keinginan }\end{array}$ \\
\hline 6. & Cat & $\begin{array}{l}1 \text { warna atau } \\
\text { sesuai keinginan }\end{array}$ \\
\hline
\end{tabular}

b. Tahapan pengolahan Cengpo

1) Memisahkan kulit kelapa dari tempurungnya.

2) Kemudian mengambil serabutnya saja, lalu dipukul-pukul sampai lunak. 
4) Merapikan serabut dengan sisir dan memotongnya sama panjang.

5) Mengikat serabut tersebut pada benang sol dari ujung atau sesuai keinginan.

6) Merendam ikatan serabut tersebut ke dalam pewarna.

7) Melakukan pengecatan pada pegangan cengpo dengan cat warna, kemudian menjemurnya hingga kering.

8) Setelah kering, mengoleskan lem pada pegangan cengpo.

9) Mengikat secara melingkar serabut pada pegangan cengpo yang sudah diberi warna dari ujungnya, sisakan sebagai pegangan (usahakan ikatannya kuat agar tidak lepas).

10) Bagian ujung bawah pegangan bisa diberi gantungan.

11) Selesai.

*Catatan: Untuk alat dan bahan pembuatan Cengpo Skala Besar tergantung jumlah barang yang ingin diproduksi.

3. Pendampingan

Setelah produksi ini selesai selanjutnya adalah pendampingan pemasaran produk. Pemasaran dilakukan oleh ibu-ibu PKK dengan cara dijual di pasar-pasar atau di toko-toko. Selain itu Tim pelaksana melakukan pengawasan dan evaluasi yang bertujuan untuk mengetahui perkembangan keadaan sebelum dan setelah program ini berjalan, baik segi ekonomi maupun sosial, serta untuk memantau keberlanjutan program dengan cara mengikut sertakan kelompok Karang

\section{HASIL DAN PEMBAHASAN}

Ketercapaian dari program PKM ini yaitu pada bulan pertama pencapaian luaran produk Cengpo belum maksimal, baru mulai terlihat tercapainya luaran yang kedua dan ketiga yaitu "Peningkatan nilai guna hasil panen berupa kelapa yang merupakan komoditas utama Desa Ploso" dan "Produk "Cengpo" ini diharapkan mampu menjadi produk yang diakui dan digunakan masyarakat" karena proses pembuatan Cengpo masih terbatas dan pemasaran masih belum luas. Hanya ada beberapa kios untuk pemasaran produk Cengpo. Namun walaupun masih dalam lingkup kecil produk Cengpo ini sudah menarik minat masyarakat untuk membeli.

Pada bulan kedua perkembangan keadaan masyarakat Desa Ploso dari segi ekonomi dan segi nilai guna serabut kelapa sudah mulai menunjukan perubahan lebih baik daripada keadaan sebelum dilaksanakannya program ini. Karena pada bulan kedua produksi Cengpo meningkat daripada bulan pertama. Pada bulan ketiga sudah bisa dipastikan bahwa luaran yang pertama "Menunjang perekonomian masyarakat Desa Ploso" sudah mulai tercapai. Hal ini bisa dilihat dari segi produksi dan pemasaran yang lebih besar dari pada bulan-bulan sebelumnya. Selain itu juga dikuatkan dengan pernyataan dari beberapa warga Desa Ploso melalui angket yang kami sebar.

Tabel 3.4 Rekapitulasi Angket Keberhasilan Program

\begin{tabular}{|l|c|c|c|}
\hline $\begin{array}{c}\text { Prosentase } \\
\text { jawaban }\end{array}$ & $\begin{array}{c}\text { Bulan } \\
\text { Pertama }\end{array}$ & $\begin{array}{c}\text { Bulan } \\
\text { Kedua }\end{array}$ & $\begin{array}{c}\text { Bulan } \\
\text { Ketiga }\end{array}$ \\
\hline Ya & $10 \%$ & $50 \%$ & $80 \%$ \\
\hline Tidak & $40 \%$ & $20 \%$ & $10 \%$ \\
\hline
\end{tabular}


Winarsih, Sulis, dan Mufida, Pengolahan Cengpo 'Kemoceng K elopo' | 193

Diagram Rekapitulasi Angket Keberhasilan Program

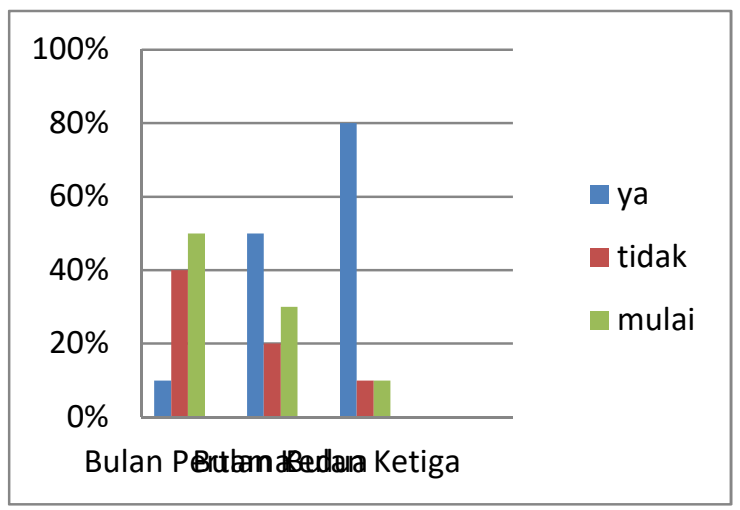

\section{PENUTUP}

\section{Simpulan}

Pelatihan Pembuatan Cengpo ini adalah pelatihan yang tujuannya untuk membekali keterampilan kepada masyarakat Desa Ploso terutama ibu-ibu PKK agar mampu mengembangkan kreatifitasnya dalam industri rumahan (home industry) dan juga untuk meningkatkan nilai guna hasil panen berupa pemanfaatan limbah serabut kelapa menjadi produk unggulan yang mampu menunjang perekonomian masyarakat Desa Ploso. Adapun, CENGPO "Kemoceng Kelopo" (bahasa jawa), yaitu kemoceng yang berasal dari serabut kelopo (kelapa). Fungsi dari kemoceng ini sama halnya dengan kemoceng pada umumnya, hanya saja terbuat dari bahan serabut kelapa. Keunggulan dari Cengpo ini adalah bahan yang digunakan mudah untuk didapatkan dan juga ramah lingkungan, selain itu cengpo tahan lama atau tidak mudah rusak.

Adapun pelakasanaan program kreatifitas mahasiswa, kami menggunakan metode pelatihan Cengpo dibagi menjadi tiga waktu: (1) tahap penyuluhan, (2) pelatihan, dan (3) pendampingan iptek. perekonomian yang signifikan pada bulan kedua dan ketiga pelaksanaan program. Hal ini bisa dilihat dari segi produksi dan pemasaran yang lebih besar dari pada bulanbulan sebelumnya. Selain itu juga dikuatkan dengan pernyataan dari beberapa warga Desa Ploso melalui angket keberhasilan program.

\section{Saran}

Hasil pelaksanaan program pelatihan pengolahan cengpo "kemoceng kelopo" diharapkan mampu melengkapi kajian mengenai pemanfaatan limbah serabut kelapa yang selama ini belum maksimal. Khususnya untuk masyarakat pedesaan yang kebanyakan memiliki kebun kelapa sendiri, hal ini bisa jadikan sebagai suatu motivasi agar masyarakat bisa lebih kreatif dalam pemanfaatan kearifan lokal budaya yang ada secara maksimal. Namun, bagi peneliti lain yang tertarik pada program ini dapat dijadikan referensi untuk diadakan pengembangan program lanjutan dengan model dan varians cengpo yang baru.

\section{DAFTAR PUSTAKA}

Basu Swasta. 2008. Manajemen Pemasaran Modern. Yogyakarta : Universitas Gadjah Mada

Jaka Permana. 2006. Membangun Industri Kecil Di Desa. Bandung : CV. Putra Setia

Usman Rianse Dan Abdi. 2012. Metododlogi Penelitian Sosial Dan Ekonomi. Bandung : Alfabeta

https://mesinpengolahansabutkelapa.wordpr ess.com/2016/06/23/manfaat-sabutkelapa-bagi-kehidupan-sehari-hari/ 